\title{
Determination of the Engineering Properties of Submarine Soil Layers in the Bohai Sea Using the Piezocone Penetration Test
}

\author{
Bohong Wu, ${ }^{1,2}$ Guihe Wang, ${ }^{1,3}$ Jiong Li $\mathbb{D}^{1,3}$ Yu Wang $\mathbb{D}^{1,3}$ and Baolin Liu $\mathbb{D}^{1,3}$ \\ ${ }^{1}$ Key Laboratory on Deep Geo-Drilling Technology of the Ministry of Land and Resources, \\ China University of Geosciences, Beijing 100083, China \\ ${ }^{2}$ Institutes of Science and Development, Chinese Academy of Sciences, Beijing 100190, China \\ ${ }^{3}$ School of Engineering and Technology, China University of Geosciences, Beijing 100083, China \\ Correspondence should be addressed to Jiong Li; 1943356572@qq.com
}

Received 2 August 2018; Accepted 7 November 2018; Published 5 December 2018

Academic Editor: Hossein Moayedi

Copyright (c) 2018 Bohong $\mathrm{Wu}$ et al. This is an open access article distributed under the Creative Commons Attribution License, which permits unrestricted use, distribution, and reproduction in any medium, provided the original work is properly cited.

\begin{abstract}
Due to the complexity of marine geotechnical engineering, the harsh operating environments, loose subsea soils, and high water contents, it is extremely difficult to obtain soil samples while maintaining the in situ conditions in offshore areas. The engineering properties of submarine soil layers in the Bohai Sea, China, were investigated in this work. The Wison-APB borehole wireline piezocone penetration test (CPTU) system was used to conduct direct measurements of the cone tip resistance, sleeve friction, and pore pressure. The soil classification and the related soil properties, such as the undrained shear strength, sensitivity and overconsolidation ratio, shear strength profile at the investigation depths, and the single pile foundation bearing capacity, were estimated. Laboratory tests were also conducted in this work. The CPT test results show that there were large differences between the results of the CPT tests $\left(S_{\mathrm{u}}\right)$ and the laboratory experimental results, which may be due to the compact silt and hard clay interbeds in some layers. The soil classification was determined according to the previous literature. The laboratory test results of the undrained shear strength, clay sensitivity, and the OCR match the CPT test results best when the parameters $N_{\mathrm{kt}}, N_{\mathrm{s}}$, and $k$ are 15,6 , and 0.3 , respectively. The final determination of the ultimate pile capacity depends on the soil's mechanical properties and the pile type and design. The effects of wave surge and wind loading should also be taken into account in offshore engineering.
\end{abstract}

\section{Introduction}

Coring, sampling, and laboratory soil mechanical testing used to be a common practice to understand and classify foundation soils and their properties [1-5]. However, due to the loose structure and high water content of the submarine soil, it is difficult and expensive to obtain in situ subsea soil samples. The cone penetration test and piezocone penetration test (CPT/CPTU) while drilling is a mature and timesaving in situ test method that can be used to continuously measure the soil mechanical properties without disturbing the soil's in situ stress [6]. Moreover, the test results can be correlated with drilling samples from key locations for further data validation and correction. Based on CPT test results, engineers can accurately classify the subsea layers and determine the soil mechanical parameters at a construction site. The mechanical parameters including the undrained shear strength, sensitivity, overconsolidation ratio, and foundation bearing capacity can be obtained. By providing an accurate and reliable basis for engineering design, the CPT/CPTU method is playing an increasingly important role in offshore oil and gas exploration platform construction, subsea pipeline and cable deployment, coastal zone development, and harbor construction [6-9].

The CPT technique has been widely used in onshore geotechnical engineering, and many empirical equations have been developed for use in local geological investigations $[10,11]$. The offshore CPT technique, its operational procedure, and theoretical characteristics have been studied in many countries [12]. However, the application of offshore CPT is still in its initial phase in China $[13,14]$. Since 1948, when the Dutch civil engineer Bakker invented the first 
electronic CPT probe, the Dutch Delft Soil Mechanics Lab and other institutes have developed several kinds of electronic CPT probes, and the CPT technique is now widely used. In the 1960s, CPT equipment was modified for use in coastal waters, but it could only be used at limited water depths until the past decade. The British manufacturer DATEM designed and produced a mini CPT that can be used in $300 \mathrm{~m}$ of water and has a probe investigation depth of $10 \mathrm{~m} \mathrm{[15].} \mathrm{Up} \mathrm{to} \mathrm{now,} \mathrm{one} \mathrm{of} \mathrm{the} \mathrm{most} \mathrm{advanced} \mathrm{offshore}$ CPT systems, the Roson seabed CPT system and Wison wireline CPT system, is produced by the Dutch manufacturer a.p.v.d Berg [16]. The Roson seabed CPT is capable of performing CPT tests at 25-30 locations that can be located several kilometers from each other. The probe penetration depth can reach 3-5 m. In 1954, Chen Zongji introduced a CPT technique from the Netherlands and performed several basic tests in the loess region of China [17]. Wang [13] developed the first electronic CPT system in China. Despite recent developments and improvements, few experimental studies of the CPT testing technique have been conducted. In 1973, the Institute of Oceanology, Chinese Academy of Science, successfully developed a seabed CPT system. However, it could only be used in siltclay formations to a maximum water depth of $50 \mathrm{~m}$. In 2005, the Guangzhou Marine Geological Survey led the national scientific research project "Marine Soil Mechanics In-Situ Testing Technique," which developed an offshore system that implemented the key technology of an inner hydraulic pressure assembly pushing system. The working water depth reached $100 \mathrm{~m}$, and the maximum probing depth was $120 \mathrm{~m}$. However, due to the mechanical design, the system could not be used in deeper water. In 2007, China Oilfield Services Limited (COSL) imported the first wireline offshore CPT system from the Dutch manufacturer a.p.v.d Berg. Since then, COSL has performed many geotechnical explorations for offshore oil and gas platform design and installation.

CPT test results can be used to evaluate the engineering properties of marine soil, such as the foundation bearing capacity, compressibility, estimated undrained shear strength, overconsolidation ratio, and sensitivity. Senneset [18] and Campanella et al. [19] proposed using the effective cone tip stress to calculate the soil's undrained shear strength. Based on CPT and laboratory triaxial testing results of North Sea clay, Lunne and Lacasse [20] proposed an empirical equation that is still widely used all over the world. For example, Rémai [4], Robertson et al. [21], and Mayne [3] utilized CPT results to calculate the sensitivity and overconsolidation ratio. $\mathrm{Hu}$ et al. [22] proposed a new prediction method of total shaft resistance to predict the sinking resistance of jacked piles with CPT in a multilayer soil at the Pearl river delta alluvial plain. Studies of the application of CPTs in geotechnical investigations have mainly focused on onshore projects. Offshore and marine CPT applications began relatively late, and little research data have been obtained [23]. Cai et al. [24] studied the undrained shear strength from piezocone penetration tests in soft marine clay in Jiangsu Province. Similarly, the undrained shear strength of marine clay at South Pars field in Iran was evaluated using cone penetration resistance by Ebrahimian et al. [11]. A similar method was used by Li et al. [25] in the South China Sea. A rapid method was promoted for determining the horizontal bearing capacity of pile foundation. The $p-y$ curve method was used to evaluate the soil resistance development characteristics based on CPTU data [26]. The geotechnical properties of clay sediments in the Romanian sector of the Black Sea were investigated by Ballas et al. [27] using laboratory and in situ measurements as part of the geohazard assessment in the Romanian sector of the Black Sea affected by landslides and seafloor deformation features. Based on the CPTU's results and analysis, Ballas et al. [27] found that a shallow increase in shear strength exceeding the general trend could have been reconciled with evidence for the precipitation of iron sulfides and calcium carbonates related to early diagenetic reactions of sulfate reduction and anaerobic oxidation of methane. Artificial intelligence (AI) model was developed to predict the load-settlement behavior of single piles by the Nejad and Jaksa [28] and Moayedi and Hayati [29]. Nejad and Jaksa [28] developed an artificial neural network (ANN) model to predict the behavior of piles based on approximately $500 \mathrm{CPT}$ datasets. He compared the results predicted by ANN methods with those given by traditional methods and found out that the model showed an acceptable degree of accuracy, which can be used as an accurate and quick tool for estimating the behavior of piles. Moayedi and Hayati [29] used static feedforward neural network (FFNN) and dynamic focused time-delay neural network (FTDNN) model to predict the pile-bearing capacity derived from CPT results. The results predicted by his model showed a good agreement with the experimental results, which conformed the reliability of FFNN and FTDNN solution in the study.

In the 1960s and 1970s, the Chinese government and the Petroleum and Natural Gas Corporation of China began exploring for oil and gas in Bohai Bay. Until 1995, little oil and gas were discovered in this area. As seismic technology and computer data analysis methods were improved with international cooperation, more oil and gas was discovered in Bohai Bay $[30,31]$. The Xinhua Net recently announced the discovery of the Nanpu oilfield, which has reserves of 1 billion tons (China National Petroleum AG, 2016). This discovery is significant for the economic development of the Caofeidian Port Area and the Bohai region and is affecting international oil prices. The stratigraphic division and determination of the engineering properties of submarine soil layers are important in the early-stage evaluation of an oilfield and petroleum geology research. However, the engineering properties of the submarine soil layers in this area have rarely been reported in the literature $[32,33]$. Therefore, investigating the engineering properties of the submarine soil layers is important for Chinese oil exploration.

The objectives of this study are (1) to summarize the utilization of the Wison-APB borehole wireline CPTU system; (2) to measure the tip resistance, sleeve friction, 
and pore pressure of the submarine soil layers in the Bohai Sea using the Wison-APB borehole wireline CPTU system; (3) to describe the borehole soil samples and conduct a series of soil mechanical tests in the laboratory; (4) to classify the submarine soils; and (5) to evaluate the engineering properties of the submarine soils, such as the undrained shear strength, sensitivity, and overconsolidation ratio.

\section{Methodology and Process}

2.1. Background and Project Apparatus. This study was carried out in the western Bohai Sea, $280 \mathrm{~km}$ southeast of Beijing, at the coordinates $\mathrm{N} 39^{\circ} 8^{\prime} 7.22851^{\prime \prime}$ and E119 $13^{\prime} 39.65952^{\prime \prime}$ (Figure 1). The results of previous in situ investigations show that the regional strata are mainly composed of late Quaternary marine and continental sediments. Sea-land interactions significantly influence the engineering geological properties of the different sediments, which cause them to have different physical and mechanical properties $[33,34]$. In this area, the effective glaciation (ice all day) lasts between 5 and 29 days with a historical average of 16 days. The average first day of ice is on November 23, and the average final day of ice is March 8 . The average annual temperature is $13.6^{\circ} \mathrm{C}$. The results of on site investigations show that the oil reservoir could cover a total area of up to $38.54 \mathrm{~km}^{2}$, the total crude oil reserves are $7689.58 \times 10^{4} \mathrm{t}$, and the total gas reserves are almost $42.2 \times 10^{8} \mathrm{~m}^{3}$.

The objective of this study is to perform a geotechnical engineering investigation on an oilfield during its second phase of development to determine the physical and mechanical properties of the subsea soils for future offshore platform designs and installations. A Wison-APB downhole wireline CPT system was used (Figure 2). The Wison-APB CPT system includes the following components: CPTU probe (Figure 3), cable pushing system, hydraulic winch with an umbilical cable, remote control system and acquisition unit, depth encoder, and a guiding wheel.

Two stroke length options are available in the WisonSPB system. The Wison-APB $(100 \mathrm{kN})$, which has a $3000 \mathrm{~mm}$ stroke length, is mainly used to push the CPTU or seismic probe into the soil, whereas the Wison-APB $(50 \mathrm{kN})$, which has a $1000 \mathrm{~mm}$ stroke length, is designed for various samples and vane testers. The specifications of the system and probe are shown in Table 1.

The geotechnical engineering investigation included 3 well site slots and a single point mooring system. Four boreholes with a total length of $475.3 \mathrm{~m}$ were drilled, and the CPTU was used in 6 boreholes with a total length of $260.5 \mathrm{~m}$. The data used in this paper are mainly from the deepest borehole, which was $113 \mathrm{~m}$ deep. The entire investigation was performed on a geotechnical drilling vessel. The water depth was $27.7 \mathrm{~m}$. Reverse circulation was used in the drilling process. After the borehole was drilled to the planned depth, the rig crew performed open hole cleaning. The drilling equipment included a hydraulic top drive, mud pumps, a heave compensator (20 ton) with a $3 \mathrm{~m}$ stroke length, a 5" IF API drill pipe, a drill bit, and a Fugro WIP hydraulic sampler. The soil sample descriptions followed the U.S. ASTM standard [35].

The laboratory tests, including a critical moisture content test, an undrained triaxial test, and an electric vane shear test, were all conducted in the Key Laboratory on Deep GeoDrilling Technology of the Ministry of Land and Resources, China University of Geosciences, Beijing. All of the tests followed ASTM standards [35-37].

2.2. Soil Classification. Based on previous research, two soil classification methods were used in this study: the methods proposed by Robertson et al. [38] and Eslami and Fellenius [39].

Using CPT test results, Robertson et al. [38] proposed a soil classification method based on the corrected value of the tip resistance $q_{\mathrm{t}}$, which can be described by a graphical method using three parameters: the pore pressure ratio $B_{\mathrm{q}}$, the friction ratio $F_{\mathrm{r}}$, and the linear normalized tip resistance $Q_{t}$ (equations (1), (2), and (3), respectively):

$$
\begin{aligned}
& B_{\mathrm{q}}=\frac{\left(u_{2}-u_{0}\right)}{\left(q_{\mathrm{t}}-\sigma_{v 0}\right)}, \\
& F_{\mathrm{r}}=\frac{f_{\mathrm{s}}}{q_{\mathrm{t}}} \\
& Q_{\mathrm{t}}=\frac{q_{\mathrm{t}}-\sigma_{v 0}}{\sigma_{v 0}^{\prime}},
\end{aligned}
$$

where $\sigma_{v 0}^{\prime}$ is the effective overburden earth pressure, $u_{2}$ is the cone measured pore pressure, $\sigma_{v 0}$ is the total overburden stress (including pore pressure), and $f_{\mathrm{s}}$ is the sleeve friction. The results from previous investigations show that this method can accurately classify soils.

Based on the CPT test results for pile foundation designs, Eslami and Fellenius [39] proposed a soil classification method that uses the relationship between the effective tip resistance and side friction with the following equations:

$$
\begin{aligned}
& q_{\mathrm{e}}=q_{\mathrm{t}}-u_{2}, \\
& q_{\mathrm{e}}=q_{\mathrm{c}}-0.84 u_{2},
\end{aligned}
$$

where $q_{\mathrm{e}}$ is the effective tip resistance.

\subsection{Methodology to Calculate the Subsea Soil's Mechanical Properties}

2.3.1. Undrained Shear Strength Calculation. Three main methods can be used to estimate the undrained shear strength: the total cone resistance estimation method, the effective cone resistance estimation method, and the excess pore pressure $(\Delta u)$ estimation method. The most common method is based on correcting the cone resistance to evaluate the undrained shear strength $S_{\mathrm{u}}$ [15], which is expressed as follows: 


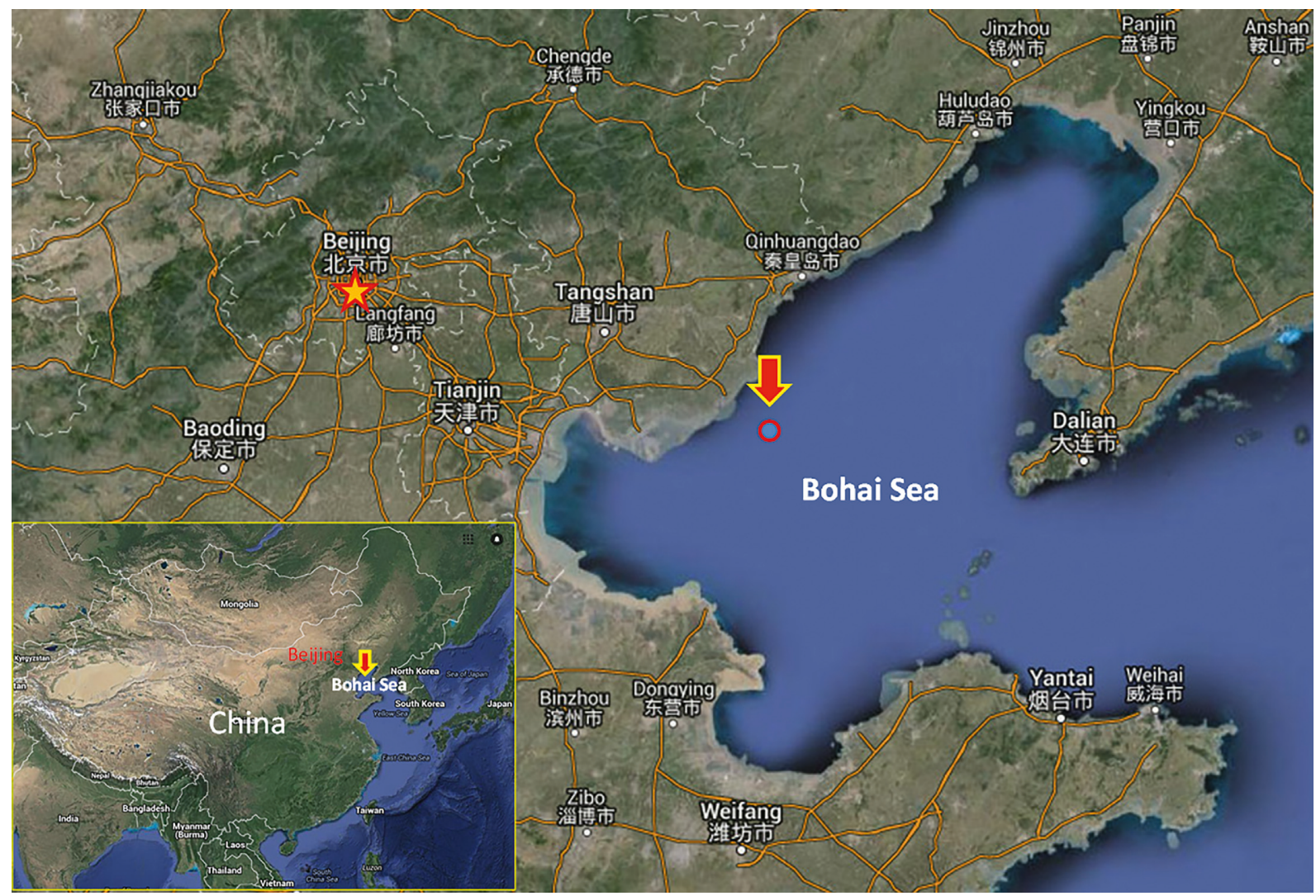

Figure 1: Location of the research site.

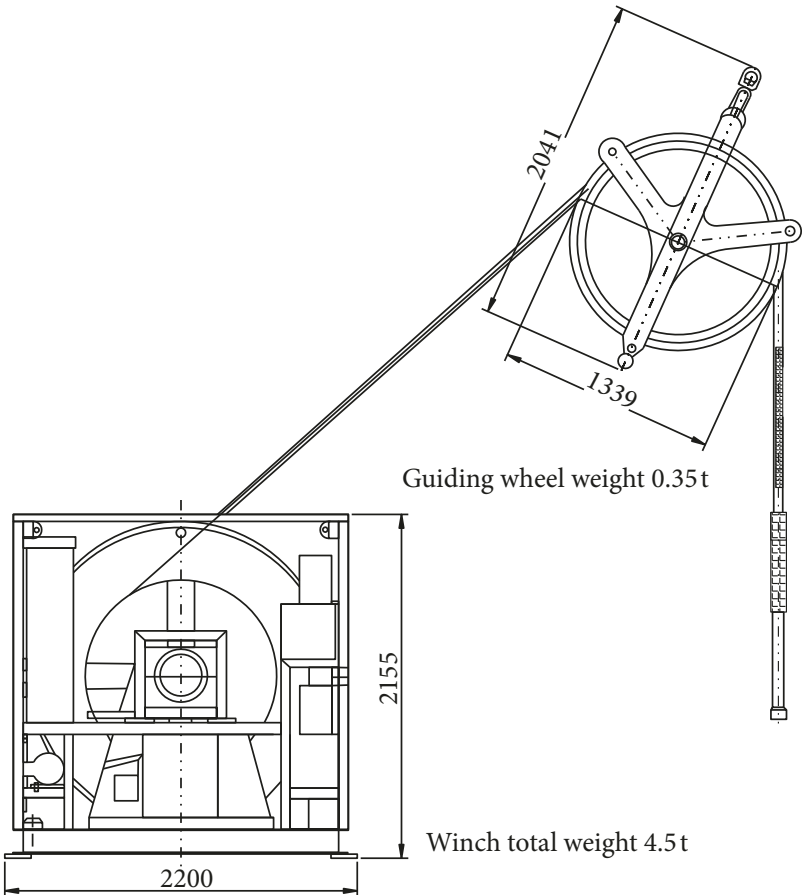

Figure 2: Wison-APB downhole CPT system (AP van den Berg, [34].

$$
q_{\mathrm{t}}=q_{\mathrm{c}}+u_{2}(1-\alpha)
$$

where $S_{\mathrm{u}}$ represents the undrained shear strength, $\sigma_{v 0}$ represents the overburden pressure, $N_{\mathrm{kt}}$ represents the cone tip coefficient, which ranges from 4 to $30, q_{c}$ is the cone tip resistance, and $u_{2}$ and $\alpha$ is the corrected cone tip area ratio, which was chosen as 0.84 in this paper. The value of $N_{\mathrm{kt}}$ depends on many variables, such as the undrained shear strength test method that is used in the laboratory, the in situ soil stress history, the soil structures, the soil sensitivity, and the CPT penetration speed.

2.3.2. Clay Sensitivity Calculation. The clay sensitivity is defined as the ratio of the undisturbed soil shear strength to the disturbed soil shear strength (equation (7)). Among in situ tests, the results of vane shear tests can be used to determine the in situ soil sensitivity. However, vane tests are not suitable in the subsea environment, and the CPTU technique is an ideal alternative to evaluate the in situ soil sensitivity. The sleeve friction is a function of the disturbed undrained soil shear strength. Schmertman [40] suggested that the soil sensitivity can be derived from the frictional ratio as shown in equations (8) and (9):

$$
S_{\mathrm{t}}=\frac{S_{\mathrm{u}}}{S_{\mathrm{ur}}}
$$




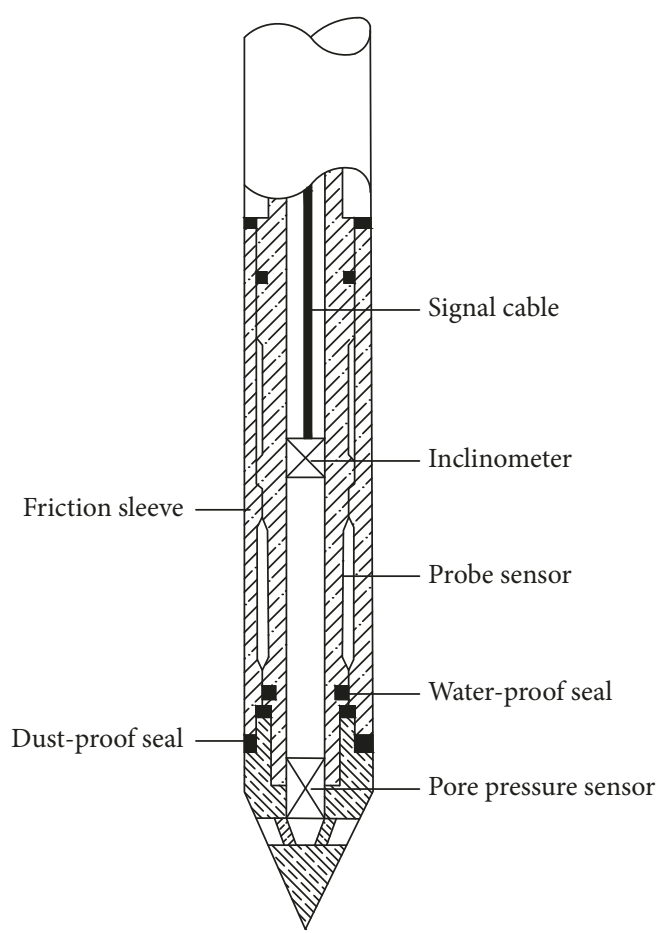

(a)

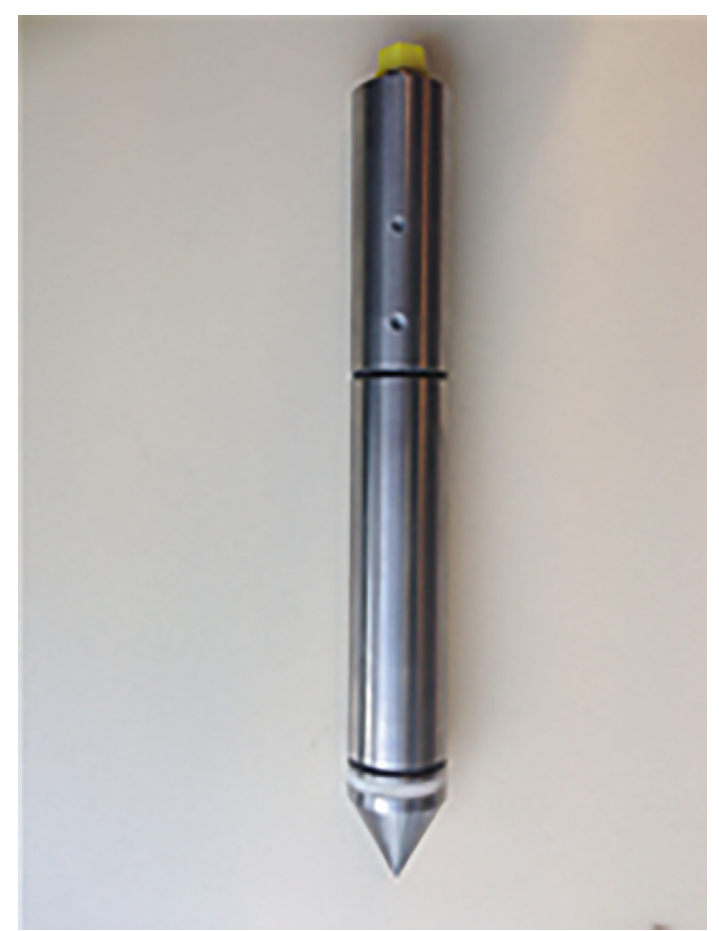

(b)

Figure 3: Pore pressure probe of the Wison-APB downhole CPT.

TABLE 1: Technical parameters of the Wison-APB 50/100 kN (AP van den Berg, [34].

\begin{tabular}{|c|c|c|c|}
\hline Specifications & Wison-APB & Parameters & Value/notes \\
\hline Pushing force $(\mathrm{kN})$ & $50 / 100$ & \multicolumn{2}{|c|}{ Dimensions } \\
\hline $\begin{array}{l}\text { Hydraulic tank working pressure } \\
(\mathrm{MPa})\end{array}$ & $17.5 / 35.0$ & $\begin{array}{l}\text { Total length including water hose } \\
(\mathrm{mm})\end{array}$ & $8550 / 4550$ \\
\hline Stroke length $(\mathrm{m})$ & $3.0 / 1.0$ & Maximum O.D. (mm) & 90 \\
\hline Probe specifications & & Hydraulic tank O.D./I.D. (mm) & $85 / 70$ \\
\hline Cone resistance $(\mathrm{MPa})$ & $0-100( \pm 0.1 \mathrm{MPa})$ & Drill pipe O.D./I.D. (mm) & $35 / 16$ \\
\hline Sleeve friction $(\mathrm{MPa})$ & $0-75( \pm 0.1 \mathrm{MPa})$ & Seawater proof & Yes \\
\hline Pore pressure $(\mathrm{MPa})$ & $0-1,2,5(0.5 \%)$ & Hydraulic tank & Stainless steel \\
\hline Drill pipe & $\begin{array}{l}100 \text { chromium alloy } \\
\text { electroplating }\end{array}$ & Other parts & $\begin{array}{c}\text { Stainless steel; seawater-resistant } \\
\text { copper }\end{array}$ \\
\hline
\end{tabular}

where $S_{\mathrm{u}}$ is the undisturbed undrained shear strength of the soil and $S_{\text {ur }}$ is the soil's disturbed undrained shear strength.

$$
\begin{gathered}
S_{\mathrm{t}}=\frac{N_{\mathrm{s}}}{R_{\mathrm{f}}}, \\
R_{\mathrm{f}}(\%)=\frac{f_{\mathrm{s}}}{q_{\mathrm{t}}} \times 100,
\end{gathered}
$$

where $N_{s}$ is a dimensionless coefficient, which ranges from 5 to 100 [19], $R_{\mathrm{f}}$ is the friction ratio, and $f_{\mathrm{s}}$ is the sleeve friction.

2.3.3. Clay Overconsolidation Ratio (OCR) Calculation. The soil's stress history is commonly expressed as the overconsolidation ratio (OCR) as in

$$
\text { OCR }=\frac{p_{\mathrm{c}}^{\prime}}{\sigma_{v 0}^{\prime}} .
$$

The existing overburden stress $\sigma_{v 0}^{\prime}$ can be directly calculated from the measured buoyant density, and the preconsolidation pressure $p^{\prime}$ can be obtained from consolidation tests. The OCR can also be calculated by laboratory tests using the clay's undrained shear strength $\left(S_{\mathrm{u}}\right)$, plasticity index $\left(I_{\mathrm{p}}\right)$, and effective overburden stress $\left(\sigma_{v 0}^{\prime}\right)$ as shown in the following equations:

$$
\begin{aligned}
\text { OCR } & =\left(\frac{S_{\mathrm{u}}}{S_{\mathrm{u}, \mathrm{nc}}}\right)^{1.2}, \\
S_{\mathrm{u}, \mathrm{nc}} & =\sigma_{v 0}^{\prime}\left(0.11+0.0037 I_{\mathrm{p}}\right) .
\end{aligned}
$$


Numerous methods of calculating the OCR from the pore pressure and the cone tip resistance have been developed since the 1980s, such as the undrained shear strength evaluation method [41] and direct evaluation using CPTU measurements [42-44]. One of the most common methods is to use Mayne's theory with cavity expansion and critical state concepts to determine the OCR in clays, as shown in the following equation:

$$
\mathrm{OCR}=k\left(\frac{q_{\mathrm{t}}-\sigma_{\nu 0}}{\sigma_{v 0}^{\prime}}\right),
$$

where $k$ is the dimensionless coefficient, which ranges from 0.2 to 0.5 .

2.4. Correction Methodology. The limit moisture content test, the unconsolidated undrained triaxial test, and the electrical vane shear test follow the ASTM standards, the National Standards of the People's Republic of China, Code for Investigation of Geotechnical Engineering (GB 50021-2001), and the China Geological Survey Bureau of Geological Survey of Technical Standards, Coastal (Sea) Environmental Geological Survey Specification (DD201206) $[45,46]$. The pore pressure at the bottom of the cone tip and the friction sleeve cross section will affect the measurements of the cone tip resistance and sleeve friction. The influence varies by the type of soil. For example, in saturated soft clays, the pore pressure is relatively high, whereas the cone tip resistance is low. In this case, the oil type significantly influences the measurements, and furthermore, corrections are required. In this paper, the corrections to the cone tip resistance and sleeve friction are based on the diagram of cross-sectional area differences (Figure 4). The correction function is shown in equations (14)-(16).

If the pore pressure sensor is located at the bottom of the cone to measure the pore pressure $u_{2}$, the cone resistance can be corrected as follows:

$$
q_{\mathrm{t}}=q_{\mathrm{c}}+u_{2}\left(1-\frac{A_{\mathrm{n}}}{A_{\mathrm{q}}}\right) .
$$

Considering $a=A_{\mathrm{n}} / A_{\mathrm{q}}$ and equation (10),

$$
q_{\mathrm{t}}=q_{\mathrm{c}}+u_{2}(1-a)
$$

where $q_{\mathrm{t}}$ is the corrected cone tip resistance, $q_{\mathrm{c}}$ is the measured cone tip resistance, $u_{2}$ is the pore pressure measured at the surface of the cone sleeve, $a$ is the cone tip corrected area ratio, which is $a=0.84$ in this case, $A_{\mathrm{n}}$ is the area of the upper cone section without pore pressure, and $A_{\mathrm{q}}$ is the projected area of the cone tip.

The sleeve friction is corrected as shown in Figure 4(b) using

$$
f_{\mathrm{t}}=f_{\mathrm{s}}-\frac{\left(u_{2} \cdot A_{\mathrm{sb}}-u_{3} \cdot A_{\mathrm{st}}\right)}{A_{\mathrm{s}}},
$$

where $f_{\mathrm{t}}$ is the corrected sleeve friction, $u_{3}$ is the pore pressure measured at the end of the friction sleeve, $A_{\mathrm{sb}}$ is the cross-sectional area at the bottom friction sleeve, $A_{\text {st }}$ is the cross-sectional area at the upper friction sleeve, and $A_{\mathrm{s}}$ is the area of the friction sleeve in the superficial area.

2.5. Estimation of the Ultimate Axial Pile Capacity. One of the initial intentions of inventing the CPT was to directly estimate the static axial pile capacity. Extensive research has focused on determining the axial-bearing capacity of a single pile in onshore projects. The ultimate axial capacity $Q_{u}$ is defined in the following equation:

$$
Q_{\mathrm{u}}=Q_{\mathrm{b}}+Q_{\mathrm{s}}=q_{\mathrm{p}} A_{\mathrm{p}}+\sum_{i=1}^{n} f_{\mathrm{pi}} A_{\mathrm{si}}
$$

where $Q_{b}$ is the pile end-bearing capacity (dominant in sand), $Q_{\mathrm{s}}$ is the pile friction capacity (dominant in clay), $q_{\mathrm{p}}$ is the unit end-bearing capacity, $A_{\mathrm{p}}$ is the cross-sectional area of the pile tip, $f_{\mathrm{pi}}$ is the average unit skin friction of layer $i, A_{\mathrm{si}}$ is the pile shaft area, and $n$ is the number of layers along the single pile. In equation (13), $A_{\mathrm{p}}$ and $A_{\mathrm{si}}$ depend on the pile foundation design, while $q_{\mathrm{p}}$ and $f_{\mathrm{p}}$ can be calculated using 3 main methods: the methods of Almeida et al. [1], Eslami and Fellenius [39], and Cai et al. [24].

2.5.1. Method of Almeida et al. Almeida et al. [1] studied pile load tests and CPT/CPTU data from driven and steel piles at eight clay sites. They proposed a method to evaluate the axial capacity of piles, in which the unit end-bearing resistance $\left(q_{\mathrm{p}}\right)$ and the pile unit skin friction $\left(f_{\mathrm{p}}\right)$ are computed from the net-corrected cone resistance $q_{\text {net }}$ :

$$
\begin{aligned}
& f_{\mathrm{p}}=\frac{\left(q_{\mathrm{t}}-\sigma_{v 0}\right)}{k_{1}}=\frac{q_{\mathrm{net}}}{k_{1}}, \\
& q_{\mathrm{p}}=\frac{\left(q_{\mathrm{t}}-\sigma_{v 0}\right)}{k_{2}}=\frac{q_{\mathrm{net}}}{k_{2}},
\end{aligned}
$$

where $q_{\mathrm{t}}$ can be calculated using equation (11) and $k_{1}$ and $k_{2}$ are constants that can be calculated as follows:

$$
\begin{aligned}
& k_{1}=12+14.9 \log \left(\frac{\left(q_{\mathrm{t}}-\sigma_{v 0}\right)}{\sigma_{v 0}^{\prime}}\right), \\
& k_{2}=\frac{N_{\mathrm{kt}}}{9},
\end{aligned}
$$

where $N_{\text {kt }}$ represents the cone tip coefficient, which ranges from 4 to 30, and the existing overburden stress $\sigma_{v 0}^{\prime}$ can be calculated directly from the measured buoyant density.

2.5.2. Method of Eslami and Fellenius. Eslami and Fellenius [39] proposed a new direct CPTU method that considers the pore pressure and applies the geometric average of the cone tip resistance to the unit end-bearing resistance $\left(q_{\mathrm{p}}\right)$ and the pile unit skin friction $\left(f_{\mathrm{p}}\right)$. Their research studied different soil types, pile capacities, and pile embedment lengths in detail, and the results were compared with static load tests. The method is expressed as 


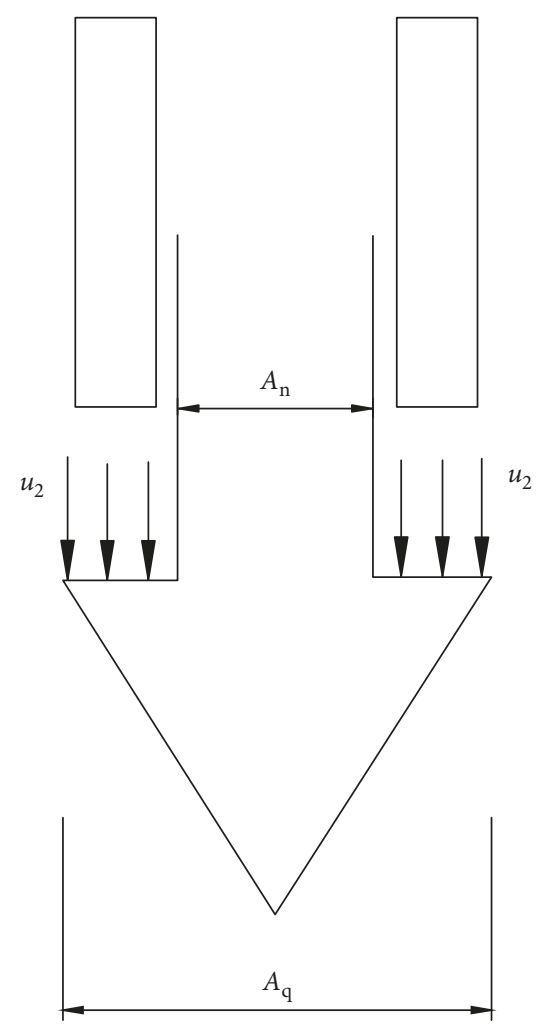

(a)

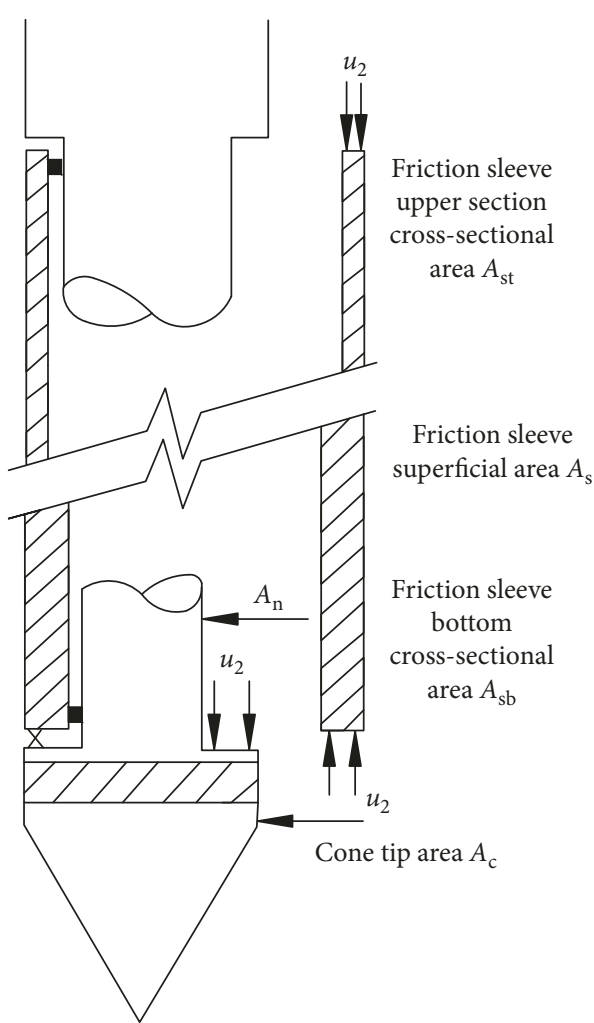

(b)

Figure 4: Schematic diagram of the unequal end area: (a) tip resistance; (b) sleeve friction.

TABle 2: Shaft correlation coefficient $C_{\mathrm{s}}$ [39].

\begin{tabular}{lcc}
\hline Soil type & \multicolumn{2}{c}{$C_{\mathrm{s}}$} \\
& Range (\%) & Approximation (\%) \\
\hline Soft sensitive soils & $7.37-8.64$ & 8.0 \\
Clay & $4.62-5.56$ & 5.0 \\
Stiff clay and mixtures of & $2.06-2.80$ & 2.5 \\
clay and silt & & 1.0 \\
Mixtures of silt and sand & $0.87-1.34$ & 0.4 \\
Sand & $0.34-0.60$ & \\
\hline
\end{tabular}

$$
q_{\mathrm{p}}=C_{\mathrm{t}} q_{\mathrm{Eg}}
$$

where $C_{\mathrm{t}}$ is the toe correlation coefficient, which is equal to unity, and $q_{\mathrm{Eg}}$ is the geometric average of the cone point resistance over the zone of influence after the correction for the pore pressure that acts behind the cone and the adjustment to the effective stress.

The pile unit shaft resistance is correlated with the average effective cone point resistance with a modification according to the soil type:

$$
f_{\mathrm{p}}=C_{\mathrm{s}} q_{\mathrm{E}}
$$

where $q_{\mathrm{E}}$ is the cone resistance after the correction for the pore pressure that acts behind the cone and the adjustment to the effective stress. The shaft correlation coefficient $\left(C_{\mathrm{s}}\right)$ is determined from Table 2.
2.5.3. Method of Cai et al. Cai et al. [47] evaluated the pile bearing capacity from piezocone penetration test data in soft Jiangsu Quaternary clay deposits and proposed an empirical evaluation method:

$$
q_{\mathrm{p}}=C_{\mathrm{q}} q_{\mathrm{e}}=C_{\mathrm{q}}\left(q_{\mathrm{t}}-u_{2}\right)
$$

where $C_{\mathrm{q}}$ is a constant for the pile unit tip resistance, which can be associated with the bearing capacity factor $N_{\mathrm{e}}$ and an empirical cone factor $N_{\mathrm{ke}}$, which can be computed from the undrained shear strength:

$$
\begin{aligned}
N_{\mathrm{ke}} & =\frac{q_{\mathrm{e}}}{S_{\mathrm{u}}} \\
C_{\mathrm{q}} & =\frac{N_{\mathrm{e}}}{N_{\mathrm{ke}}},
\end{aligned}
$$

Based on the back-analyzed results, Cai et al. [47] proposed that $C_{\mathrm{q}}$ can be expressed as follows:

$$
C_{\mathrm{q}}=\frac{8.7}{N_{\mathrm{ke}}} \text {. }
$$

The pile unit skin friction $\left(f_{\mathrm{p}}\right)$ is computed as follows: For $\Delta u_{2}<200 \mathrm{kPa}$,

$$
f_{\mathrm{p}}=\left(\frac{\Delta u_{2}+380}{250}\right) f_{\mathrm{s}} .
$$

For $200 \mathrm{kPa}<\Delta u_{2}<1000 \mathrm{kPa}$, 

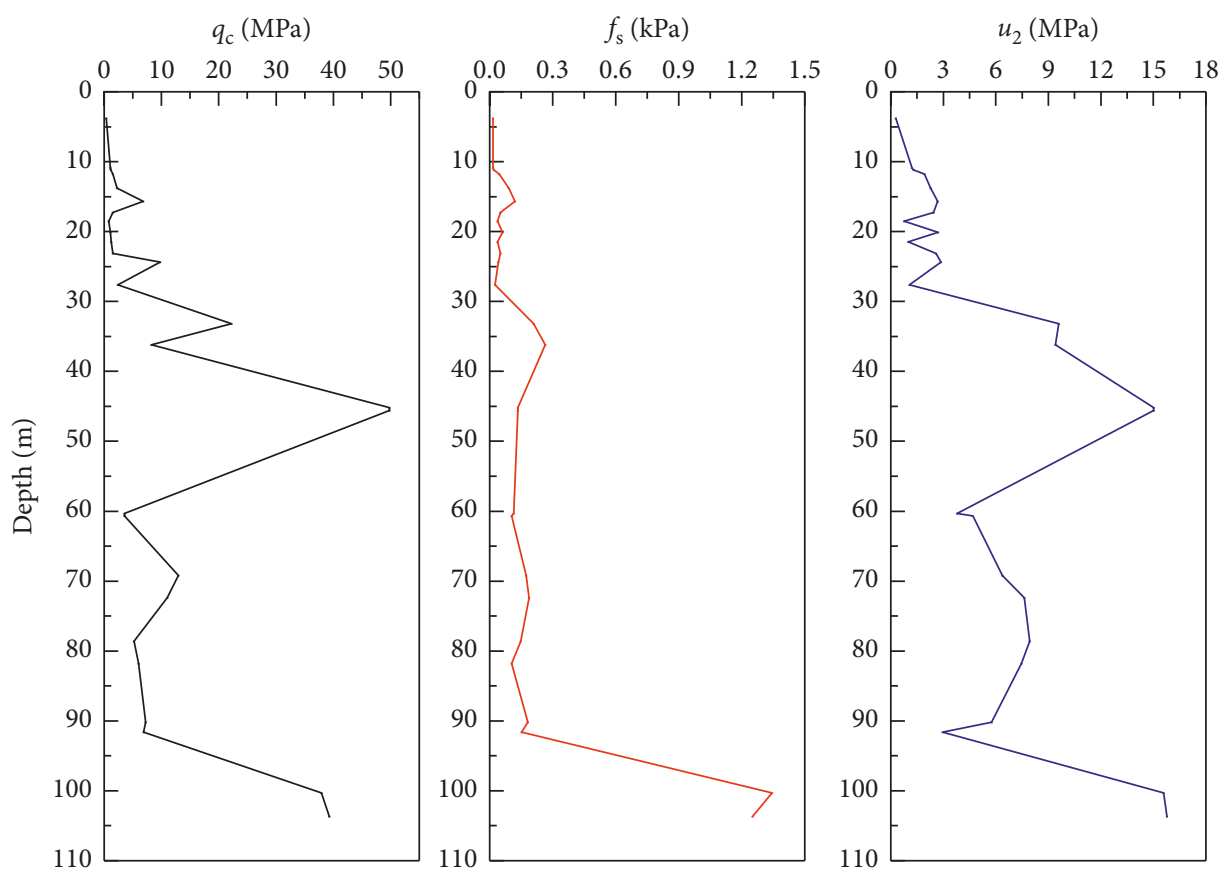

FIGURE 5: CPT test results from selected points.

$$
f_{\mathrm{p}}=\left(\frac{\Delta u_{2}+100}{125}\right) f_{\mathrm{s}}
$$

The pile unit skin friction $\left(f_{\mathrm{p}}\right)$ and unit end-bearing resistance $\left(q_{\mathrm{p}}\right)$ are calculated from the sleeve friction $\left(f_{\mathrm{s}}\right)$, excess pore water pressure $\left(\Delta u_{2}\right)$, and effective cone resistance $\left(q_{\mathrm{e}}\right)$.

Niazi [48] stated that the method proposed by Cai et al. [47] requires more information to determine the zone of influence and that Cai et al. [47] should elaborate on the influence of the installation method. Additional data and field tests are required to determine the reliability and engineering accuracy of this method.

\section{Results and Discussion}

3.1. Piezocone Penetration Test Results. In offshore geotechnical engineering, due to the saturated state of the submarine soil, excessive pore pressure is generated when the probe penetrates into the soil, which significantly affects the test results. The piezocone penetration test can measure the excessive pore pressure and its dissipation. The improvement in accuracy compared to the original measurements is remarkable. In this paper, the cone tip resistance $\left(q_{\mathrm{c}}\right)$, sleeve friction $\left(f_{\mathrm{s}}\right)$, and pore pressure $\left(u_{2}\right)$ were acquired by a Wison-APB wireline CPT system and are presented in Figure 5.

Due to variations in the permeability of the lamination layer, the cone tip resistance $\left(q_{c}\right)$ and pore pressure $\left(u_{2}\right)$ are significantly affected by the properties of the surrounding soil. As the formation varies, the cone tip resistance $\left(q_{c}\right)$ and pore pressure $\left(u_{2}\right)$ change accordingly. During the test, it was observed from Figure 5 that continuously monitoring the change in pore pressure during penetration will improve the formation classification results. Unfortunately, several test points were unsuccessful. A comparison of the CPT testderived results $\left(S_{\mathrm{u}}\right)$ to the laboratory experimental results shows several data points with significant errors, which were discarded from the results. The removed data points are at a depth of $15.7 \mathrm{~m}$ in interbedded medium compact silt and hard clay, depths of $24.35 \mathrm{~m}, 33.2 \mathrm{~m}, 69.2 \mathrm{~m}$, and $72.4 \mathrm{~m}$ in very hard clay and highly compacted silt laminations/interbeds, depths of $45.2 \mathrm{~m}, 45.6 \mathrm{~m}$, and $69.2 \mathrm{~m}$ in a hard and very hard clay formation, and at a depth of $103.65 \mathrm{~m}$ in highly compacted silt and sandy silt. The CPT results that were used are presented in Figure 5.

3.2. Soil Classification. Using the CPT test results shown in Figure 5, the parameters $B_{\mathrm{q}}, F_{\mathrm{r}}$, and $Q_{\mathrm{t}}$ were calculated using equations (1)-(3). The soil classification using the method of Robertson et al. [49] is shown in Figure 6, and the soil classification based on the method of Eslami and Fellenius [39] is shown in Figure 7.

As shown in Figures 6 and 7, the results show that the soil classification method proposed by Eslami and Fellenius [39] was better. The soil in the study area in this work is mainly composed of silt, clayey silt, silty clay, and clay-clayey silt.

3.3. Undrained Shear Strength. Based on the direct CPT measurements, the undrained shear strength of the marine soil was calculated using equations (5) and (6) with different cone tip coefficients $N_{\mathrm{kt}}$. The shear strengths from the triaxial unconsolidated undrained shear strength tests and in situ tests are shown in Figure 8.

The erroneous CPT testing points that were mentioned above can be clearly observed. The revised results after the removal of these points are shown in Figure 9. 


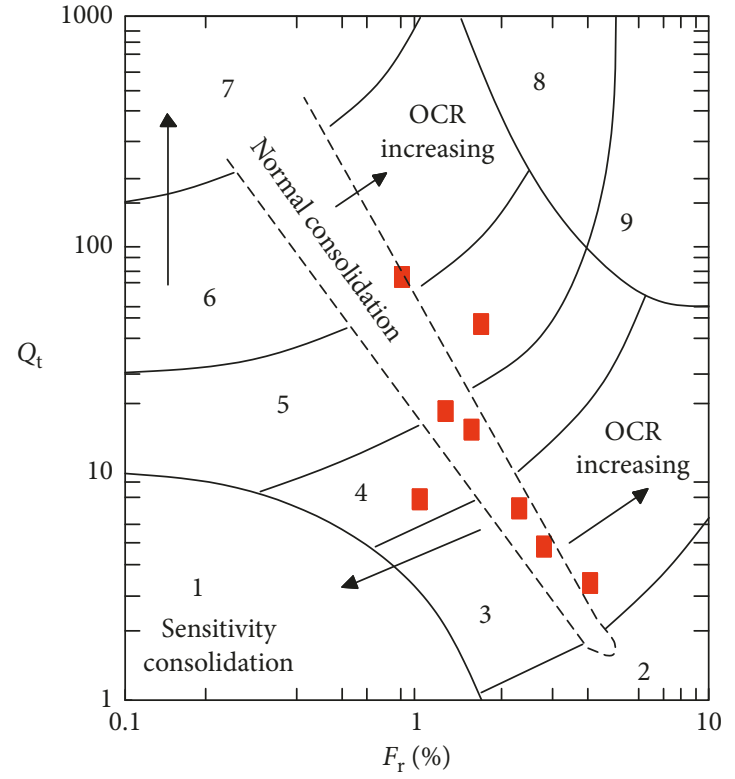

(a)

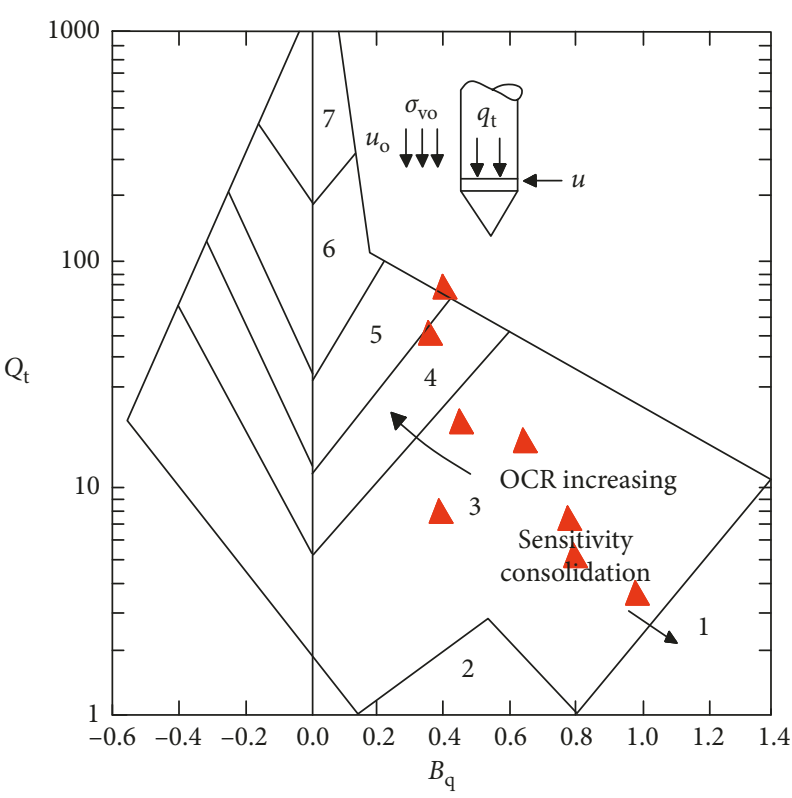

(b)

Figure 6: Soil classification using the method of Robertson [49].

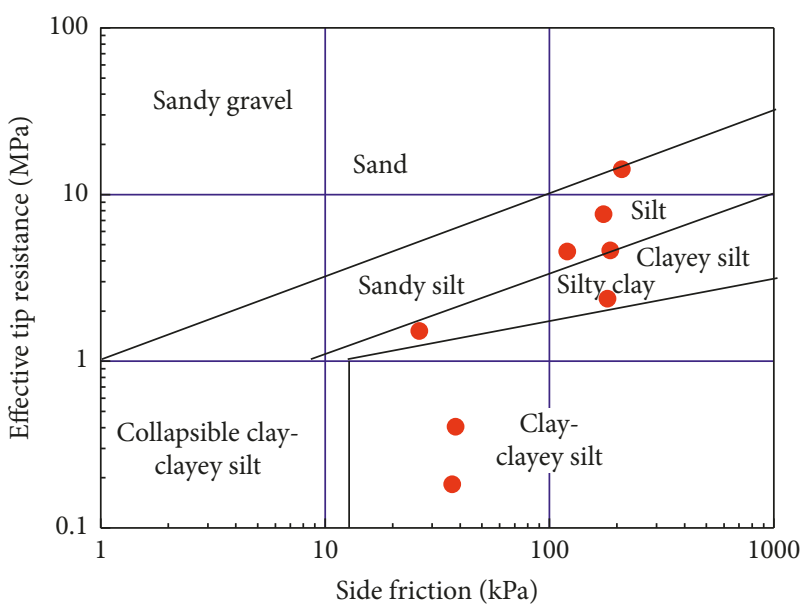

Figure 7: Soil classification using the method of Eslami and Fellenius [39].

As shown in Figure 9, the soil's shear strength increases with depth. At the studied offshore platform site, the cone tip coefficient $N_{\mathrm{kt}}$ was assumed to range from 10 to 20 . According to the variance analysis, the CPT results and laboratory results match best with a cone tip coefficient $N_{\mathrm{kt}}$ of 15. The results indicate that the CPT method is most effective for evaluating the shear strength of clay. However, the CPT method is not suitable for nonclay sediments, laminated formations or very hard clay.

3.4. Clay Sensitivity. The undrained shear strength of disturbed or undisturbed soil can be determined using an unconsolidated undrained triaxial shear test [50]. The test results are shown in Figure 10.

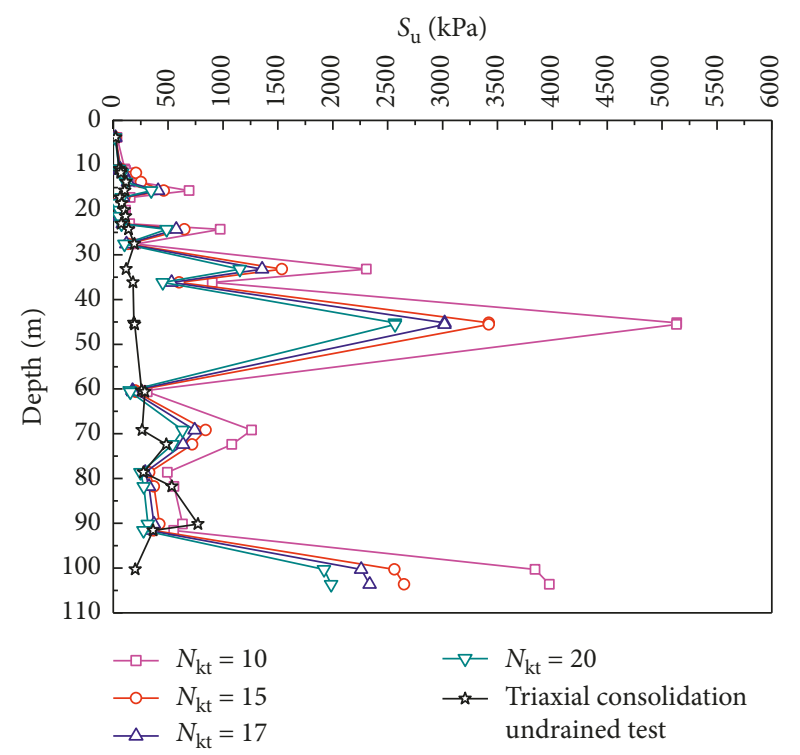

FIgURE 8: Comparison of the shear strengths from the results of undrained unconsolidated triaxial tests and CPT tests with different $N_{\text {kt }}$ values.

As shown in Figure 10, even though the shear strength fluctuates at deeper sampling depths, it generally increases with depth. Moreover, the undrained shear strength of the undisturbed soil is higher than that of the disturbed soil. The soil sensitivity can be calculated using equation (3), and the results are presented in Figure 11. The sensitivity can also be calculated based on field CPT test results using equations (4) and (5). A comparison of the sensitivity results from field $\mathrm{CPT}$ tests and laboratory tests is also shown in Figure 11.

As shown in Figure 11, the field CPT test results and laboratory test results are reasonably consistent. The 
$S_{u}(\mathrm{kPa})$

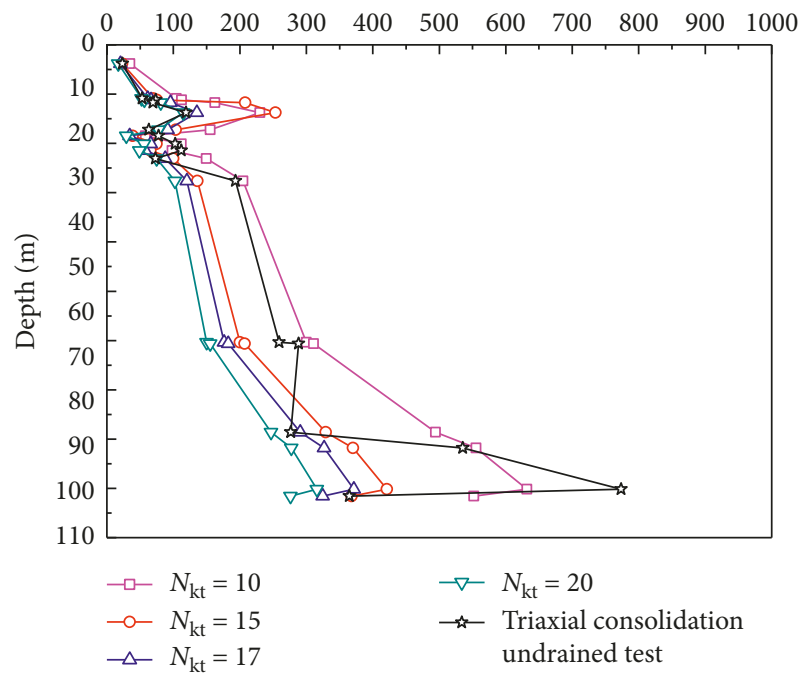

Figure 9: Revised shear strength results of undrained unconsolidated triaxial tests and CPT tests with different $N_{\mathrm{kt}}$ values (clay).

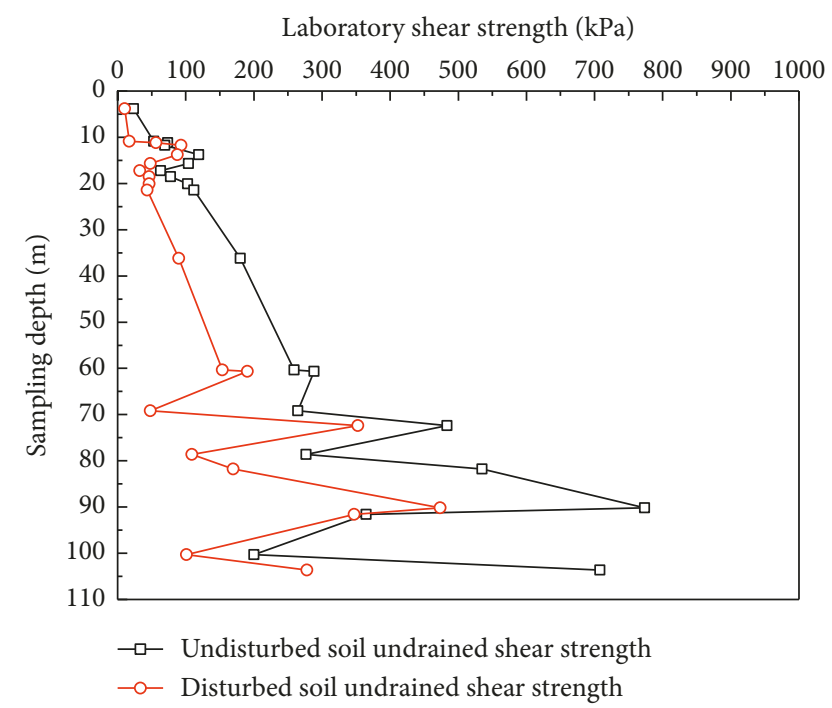

FIgURE 10: Laboratory shear strength values.

laboratory test results match the CPT test results best with a dimensionless coefficient $N_{\mathrm{s}}$ of 6 . Because of the high cost and engineering difficulty of performing in situ vane shear tests offshore, the CPT method is considered to be an ideal alternative to calculate the sensitivity of subsea clay.

3.5. OCR of Submarine Clay. The plasticity index $\left(I_{\mathrm{p}}\right)$ and triaxial shear strength $\left(S_{\mathrm{u}}\right)$ can generally be obtained from laboratory tests. The results could be used to calculate the overconsolidation ratio of clay using equations (7) and (8). The overconsolidation ratio can also be calculated based on CPT test results using equation (9) with different dimensionless coefficients for $k(0.2,0.3$, and 0.5$)$. Figure 12 shows a comparison of these two methods.

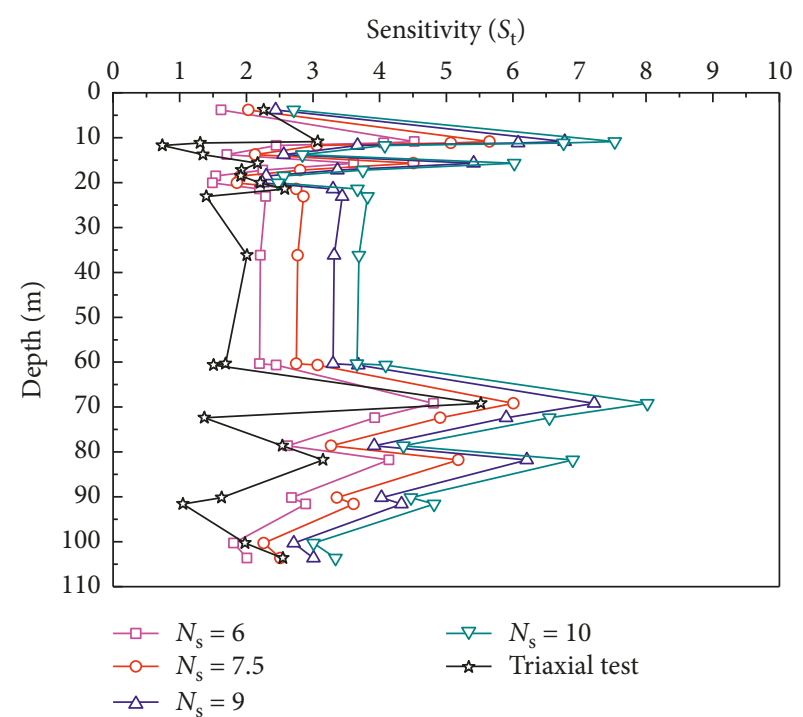

FIGURE 11: Comparison of the sensitivity results of laboratory tests and CPT tests using different $N_{\mathrm{s}}$ values.

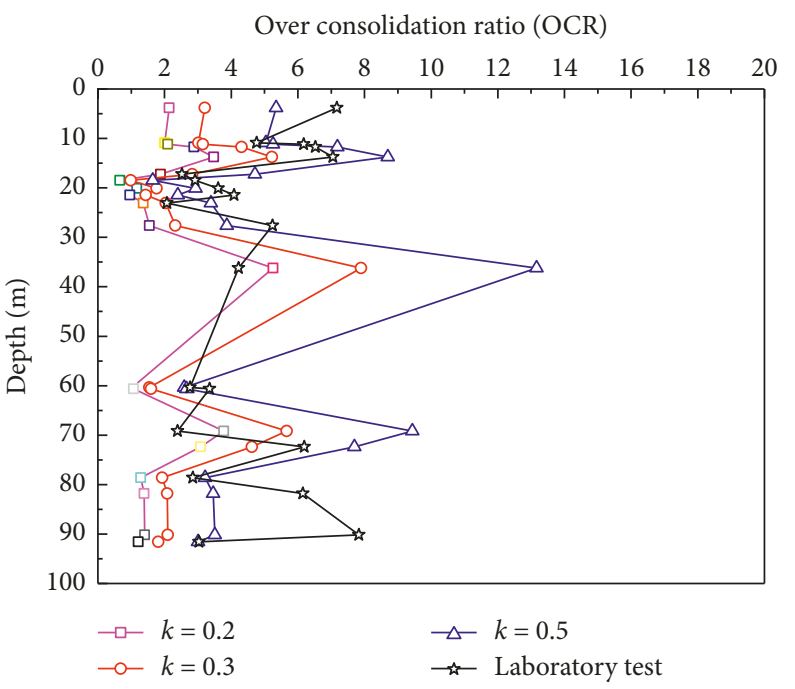

FIGURE 12: Comparison of the OCR results from laboratory tests and CPT tests with different $k$ values.

When penetrating laminated or hard formations, the errors of the CPT test results are significant. Large discrepancies between the results of field and laboratory tests indicate that a laminated or hard formation may have been penetrated. In Figure 9, the testing points with significant errors have been removed. The large discrepancies between the laboratory and field tests may have been caused by penetration through laminated or hard formations during the CPT test. As shown in Figure 12, the CPT and laboratory results have the smallest variance when $k$ is 0.3 .

3.6. Ultimate Pile Capacity. The methods of estimating the ultimate axial pile capacity were introduced previously. The final determination of the ultimate pile capacity depends on 


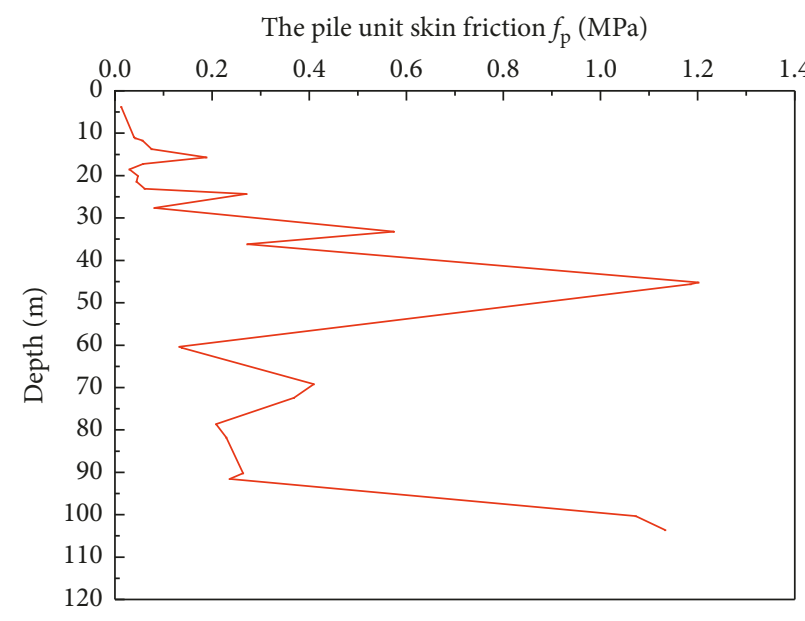

(a)

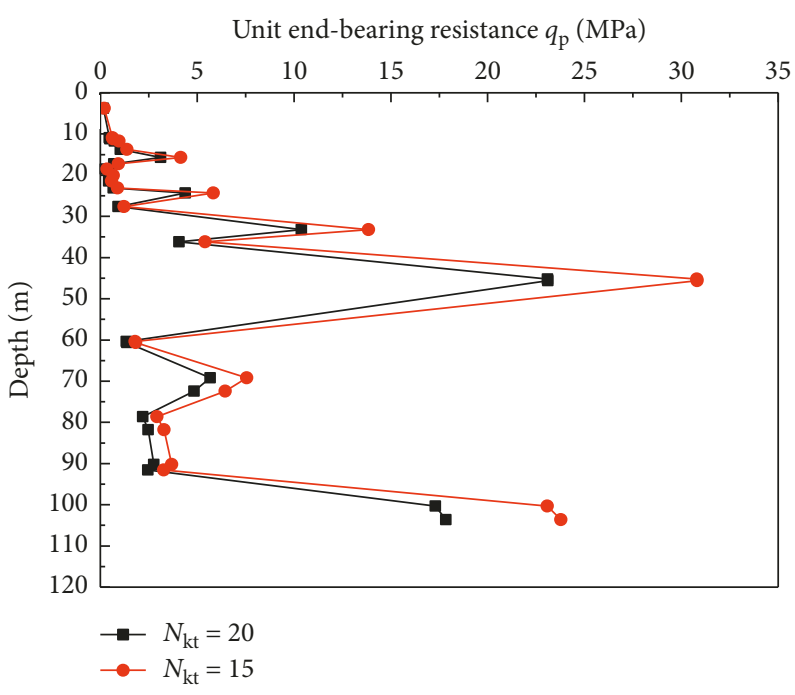

(b)

Figure 13: Calculated results for the unit end-bearing resistance $\left(q_{\mathrm{p}}\right)$ and the pile unit skin friction $\left(f_{\mathrm{p}}\right)$.

the mechanical properties of the soil and the type and design of the pile. In offshore engineering, the effects of wave surge and wind loading should be taken into account. In addition, for an offshore platform, a safety coefficient must be proposed based on the environmental loading conditions. The project presented in this paper has several advantages because it is focused on the preliminary investigation for offshore platforms, whereas the methods of Eslami and Fellenius [39] and Cai et al. [24] require information about the pile design and installation. Therefore, the method proposed by Almeida et al. [1] is most practical for calculating the unit end-bearing resistance $\left(q_{\mathrm{p}}\right)$ and pile unit skin friction $\left(f_{\mathrm{p}}\right)$ using the net-corrected cone resistance $q_{\text {net }}$. The pile unit skin friction $\left(f_{\mathrm{p}}\right)$ was computed using values of $N_{\mathrm{kt}}$ of 15 and 20 based on the results in Section 3.2. The results are shown in Figure 13.

\section{Conclusions}

The Wison-APB borehole wireline CPT system and piezocone penetration test while drilling were used to perform preliminary geotechnical investigations at an oilfield site. The CPT data were analyzed, and the physical and mechanical properties of the submarine soils were determined by comparisons with laboratory tests. The following conclusions can be drawn.

(1) There is a large difference between the results derived from the CPT tests $\left(S_{\mathrm{u}}\right)$ and the laboratory experimental results, which may be due to the compact silt and hard clay interbeds in some layers. The cone tip resistance and pore pressure measured from the downhole CPT data should be used after being corrected.

(2) The method proposed by Eslami and Fellenius [39] for soil classification was found to provide the best results.
(3) The laboratory test results of the undrained shear strength, clay sensitivity, and OCR match the CPT test results best when the parameters $N_{\mathrm{kt}}, N_{\mathrm{s}}$, and $k$ have values of 15,6 , and 0.3 , respectively.

(4) In offshore engineering, the final determination of the ultimate pile capacity depends on the mechanical properties of the soil and the type and design of the pile. Furthermore, the effects of wave surge and wind loading should be taken into account. Moreover, due to the unique characteristics of offshore platforms, a safety coefficient must be proposed based on static load tests and other tests and the environmental conditions. The piezocone penetration test or CPTU method is cost and time-saving for calculating the unit end-bearing resistance $\left(q_{\mathrm{p}}\right)$ and pile unit skin friction $\left(f_{\mathrm{p}}\right)$, which can be used to evaluate the ultimate pile capacity.

(5) The test results and proposed empirical parameters for evaluating the geotechnical properties at the studied offshore platform site are intended to provide a solid basis for future platform engineering designs.

\section{Data Availability}

The original data used to support the findings of this study were supplied by $\mathrm{Wu}$ Bohong under license and so cannot be made freely available. Requests for access to these data should be made to Wu Bohong (email id: 32779991@qq.com). The CPTU data and laboratory test data used to support the findings of this study are included within the article.

\section{Conflicts of Interest}

The authors declare that there are no conflicts of interest regarding the publication of this paper. 


\section{Acknowledgments}

This work was supported by the National Natural Science Foundation of China (no. 41672366) and the National Key Research and Development Program of China (no. 2018YFC0603404). The authors would also like to thank former researchers for their excellent work. Their results were fundamental to this study.

\section{References}

[1] M. S. S. Almeida, F. A. B. Danziger, and T. Lunne, "Use of the piezocone test to predict the axial capacity of driven and jacked piles in clay," Canadian Geotechnical Journal, vol. 33, no. 1, pp. 23-41, 1996.

[2] G. Cai, S. Liu, and A. J. Puppala, "Evaluation of pile bearing capacity from piezocone penetration test data in soft Jiangsu Quaternary clay deposits," Marine Georesources and Geotechnology, vol. 29, no. 3, pp. 177-201, 2011.

[3] P. W. Mayne, "Determination of OCR in clays by piezoncone tests using cavity expansion and critical state concepts," Soil and Foundations, vol. 31, no. 2, pp. 65-76, 1991.

[4] Z. Rémai, "Correlation of undrained shear strength and CPT resistance," Periodica Polytechnica Civil Engineering, vol. 57, no. 1, pp. 39-44, 2013.

[5] B. Tarawneh, A. Sbitnev, and Y. Hakam, "Estimation of pressuremeter modulus and limit pressure from Cone Penetration Test for desert sands," Construction and Building Materials, vol. 169, pp. 299-305, 2018.

[6] N. Sultan, M. Voisset, T. Marsset et al., "Detection of free gas and gas hydrate based on 3D seismic data and cone penetration testing: an example from the Nigerian Continental Slope," Marine Geology, vol. 240, no. 1-4, pp. 235-255, 2007.

[7] H. Ma, M. Zhou, Y. Hu, and M. S. Hossain, "Effects of cone tip roughness, in-situ stress anisotropy and strength inhomogeneity on CPT data interpretation in layered marine clays: numerical study," Engineering Geology, vol. 227, pp. 12-22, 2017.

[8] G. Rajasekaran and S. N. Rao, "Falling cone method to measure the strength of marine clays," Ocean Engineering, vol. 31, no. 14-15, pp. 1915-1927, 2004.

[9] I. L. Solberg, M. Long, V. C. Baranwal, A. S. Gylland, and J. S. Rønning, "Geophysical and geotechnical studies of geology and sediment properties at a quick-clay landslide site at Esp, Trondheim, Norway," Engineering Geology, vol. 208, pp. 214-230, 2016.

[10] Y.-F. Yu, X.-F. Zhang, and F. Li, "Experimental study on deformation modulus and oundation bearing capacity of desert sand," Geotechnical Engineering World, vol. 9, no. 6, pp. 30-32, 2006.

[11] B. Ebrahimian, V. Movahed, and A. Y. Pasha, "Evaluation of undrained shear strength of marine clay using cone penetration resistance at South Pars field in Iran," Ocean Engineering, vol. 54, pp. 182-195, 2012.

[12] T. Kalscheuer, M. Bastani, S. Donohue et al., "Delineation of a quick clay zone at Smørgrav, Norway, with electromagnetic methods under geotechnical constraints," Journal of Applied Geophysics, vol. 92, pp. 121-136, 2013.

[13] Z.-Q. Wang, "The Chinese CPT and the prospect of penetration tests," Chinese Journal of Geotechnical Engineering, vol. 22, no. 5, pp. 517-522, 2000.

[14] S. L. Shen, J. P. Wang, H. N. Wu, Y.-S. Xu, G.-L. Ye, and Z.-Y. Yin, "Evaluation of hydraulic conductivity for both marine and deltaic deposits based on piezocone testing," Ocean Engineering, vol. 110, pp. 174-182, 2015.

[15] F. Xiuli and S. Weiquan, Marine Engineering Geological Monograph, China Ocean University Press, Qingdao, China, 2006.

[16] B. Wu, The Application of Cone Penetration Test in Bohai Offshore Platform Site Investigation, 2008, in Chinese.

[17] C. Qiang-hua and Y. U. Diao-mei, “The improvement of CPT in China," Chinese Journal of Geotechnical Engineering, vol. 13, no. 1, pp. 84-95, 1991, in Chinese.

[18] K. N. Senneset, "Strength and defomation parameters form cone penetortion," in Proceedings of ESOPT II, pp. 863-870, Amsterdam, Netherlands, May 1982.

[19] R. G. Campanella, D. G. Gillespie, and P. K. Robertson, Pore Pressures during Cone Penetration Testing, Department of Civil Engineering, University of British Columbia, Vancouver, Canada, 1981.

[20] T. Lunne and S. Lacasse, "Use of in situ tests in North Sea soil investigations," Publikasjon-Norges Geotekniske Institutt, vol. 169, pp. 1-18, 1987.

[21] P. K. Robertson, R. G. Campanella, D. Gillespie et al., "Excess pore pressures and the flat dilatometer test," in Proceedings of ISOPT-1, vol. 1, pp. 567-576, Orlando, FL, USA, March 1988.

[22] Y. Q. Hu, L. S. Tang, H. T. Sang, and Z. Li, "Predicting sinking resistance of jacked piles with CPT in a multilayer soil at the pearl river delta alluvial plain," in Proceedings of the 2014 International Conference on Environmental Engineering and Computer Application (ICEECA 2014), pp. 71-75, CRC Press, Hong Kong, China, December 2014.

[23] S.-z. Guo and R. Liu, "Application of cone penetration test in offshore engineering," Chinese Journal of Geotechnical Engineering, vol. 37, no. 1, pp. 207-211, 2015, in Chinese.

[24] G. J. Cai, S. Y. Liu, L. Y. Tong, and G. Y. Du, "Field evaluation of undrained shear strength from piezocone penetration tests in soft marine clay," Marine Georesources and Geotechnology, vol. 28, no. 2, pp. 143-153, 2010.

[25] S. Li, X. Bao-Zhao, L. Jian-tao, and Z. Yang-rui, "Study of characteristics of laminated soil in South China Sea," Rock and Soil Mechanics, vol. 35, no. 1, pp. 203-209, 2014, in Chinese.

[26] H. Li, S. Liu, and L. Tong, "Study on p-y curve from cptu test and its application to horizontal bearing capacity of single pile," Chinses Journal of Rock Mechanics and Engineering, vol. 36, pp. 1-8, 2017, in Chinese.

[27] G. Ballas, S. Garziglia, N. Sultan et al., "Influence of early diagenesis on geotechnical properties of clay sediments (Romania, Black Sea)," Engineering Geology, vol. 240, pp. $175-188,2018$.

[28] F. P. Nejad and M. B. Jaksa, "Load-settlement behavior modeling of single piles using artificial neural networks and CPT data," Computers and Geotechnics, vol. 89, pp. 9-21, 2017.

[29] H. Moayedi and S. Hayati, "Applicability of a CPT-based neural network solution in predicting load-settlement responses of bored pile," International Journal of Geomechanics, vol. 18, no. 6, article 06018009, 2018.

[30] C. Liu, "Basic geologic research and development planin bohai "A" oilfield," Thesis for China University of Petroleum Master Degree, 2007, (in Chinese).

[31] http://news.xinhuanet.com/, 2007.

[32] L. Yu-ying and F.-j. Mao, "The geotechnical properties of the shallow soil layers of the southern Bohai gulf and their relationship with the sedimentary faces in the area," Marine Sciences, vol. 1, pp. 44-46, 1998, in Chinese.

[33] Q. Ya-fei, X. Qin-mian, J. Hong-tao, F. Cheng, Y. Gui-bang, and Y. Ji-long, "Physical and mechanical parameters of the 
late quaternary sediments and effect on land subsidence in the Northern Coast of Bohai Bay," Geological Survey and Research, vol. 37, no. 2, pp. 124-130, 2014.

[34] A. P. van den Berg, Ingenieursburo Wison-APB system Operating Instructions, 2007.

[35] ASTM Committee D-18 on Soil and Rock, Standard Practice for Classification of Soils for Engineering Purposes (Unified Soil Classification System), ASTM International, West Conshohocken, PA, USA, 2011.

[36] ASTM D2573/D2573M-15, Standard Test Method for Field Vane Shear Test in Saturated Fine-Grained Soils, ASTM, West Conshohocken, PA, USA, 2015.

[37] ASTM D2850-15, Standard Test Method for UnconsolidatedUndrained Triaxial Compression Test on Cohesive Soils, ASTM, West Conshohocken, PA, USA, 2015.

[38] P. K. Robertson, "Soil classification using the cone penetration test," Canadian Geotechnical Journal, vol. 27, no. 1, pp. 151158, 1990.

[39] A. Eslami and B. H. Fellenius, "Pile capacity by direct CPT and CPTu methods applied to 102 case histories," Canadian Geotechnical Journal, vol. 34, no. 6, pp. 886-904, 1997.

[40] J. H. Schmertmann, Guidelines for Cone Penetration Test: Performance and Design, Federal Highway Administration, Washington, DC, USA, 1978.

[41] J. H. Schmertmann, "Measurement of in situ shear strength, SOA Report," in Proceedings, ASCE Specialty Conference on In Situ Measurement of Soil Properties, vol. 2, pp. 57-138, Raleigh, NC, USA, 1975.

[42] M. M. Baligh, V. Vivatrat, and C. C. Ladd, "Cone penetration in soil profiling," Journal of Geotechnical and Geoenvironmental Engineering, vol. 106, 1980.

[43] T. Lunne, S. Lacasse, N. S. Rad et al., "SPT, CPT, pressuremeter testing and recent developments on in situ testing," Publikasjon-Norges Geotekniske Institutt, vol. 179, 1990.

[44] P. W. Mayne, "Determination of OCR in clays by piezoncone tests using cavity expansion and critical state concepts," Soil and Foundations, vol. 31, no. 2, pp. 65-76, 1991.

[45] China Geological Survey Bureau of Geological Survey of Technical Standards, Coastal (Sea), Environmental Geological Survey Specification (DD2012-06), China Geological Survey Bureau, China, 2012, in Chinese.

[46] National Standards of People's Republic of China, Code for Investigation of Geotechnical Engineering (GB 50021-2001), National Standards of People's Republic of China, China, 2001, in Chinese.

[47] G. Cai, S. Liu, and A. J. Puppala, "Comparison of CPT charts for soil classification using PCPT data: example from clay deposits in Jiangsu Province, China," Engineering Geology, vol. 121, no. 1-2, pp. 89-96, 2011.

[48] F. S. Niazi, "Discussion: Cai et al. evaluation of pile bearing capacity from piezocone penetration test data in soft Jiangsu Quaternary Clay Deposits," Marine Georesources and Geotechnology, vol. 33, no. 1, pp. 67-71, 2015.

[49] P. K. Robertson, "Soil classification using the cone penetration test," Canadian Geotechnical Journal, vol. 27, no. 1, pp. 151158, 1990.

[50] K. Terzaghi, R. B. Peck, and G. Mesri, Soil Mechanics in Engineering Practice, John Wiley and Sons, Hoboken, NJ, USA, 1996. 


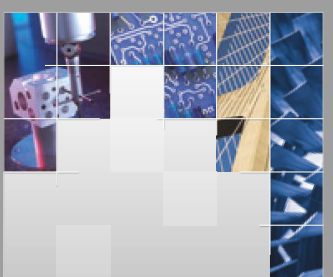

\section{Enfincering}
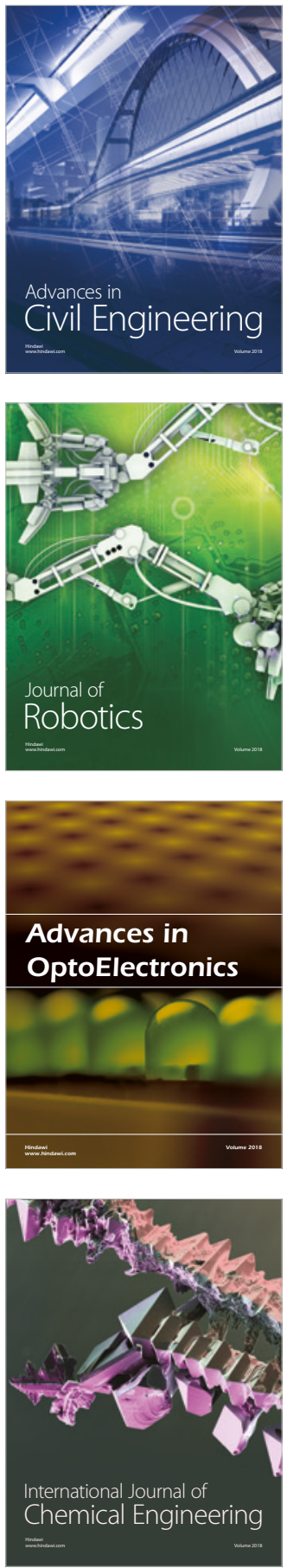

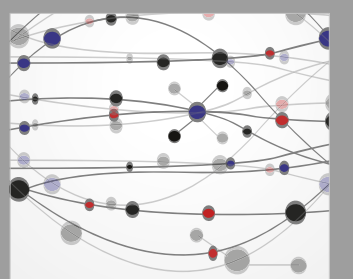

\section{Rotating \\ Machinery}

The Scientific World Journal

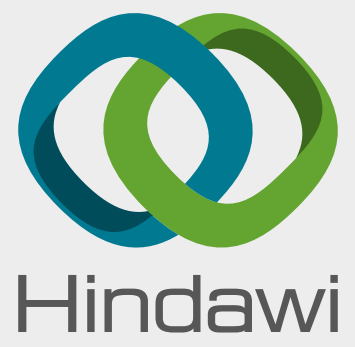

Submit your manuscripts at

www.hindawi.com
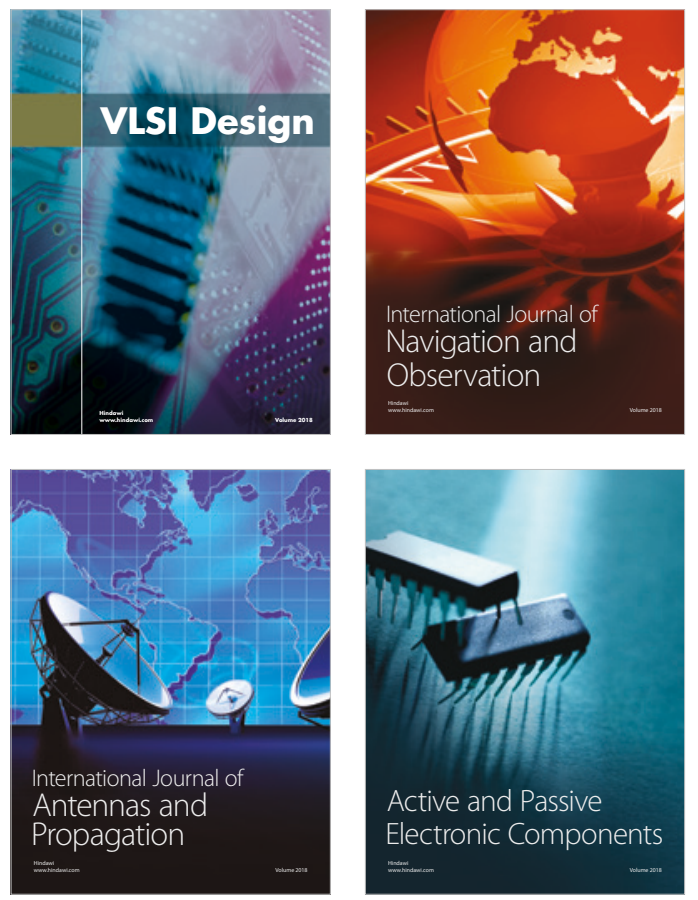
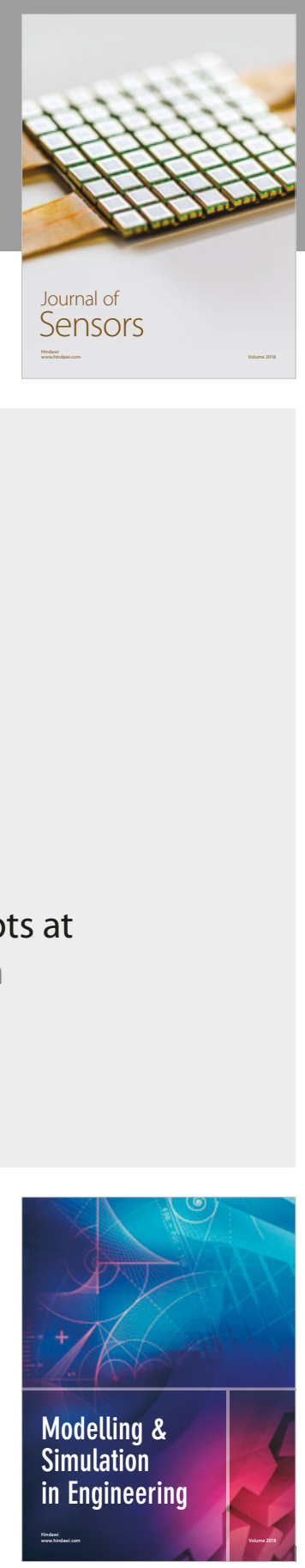

\section{Advances \\ Multimedia}
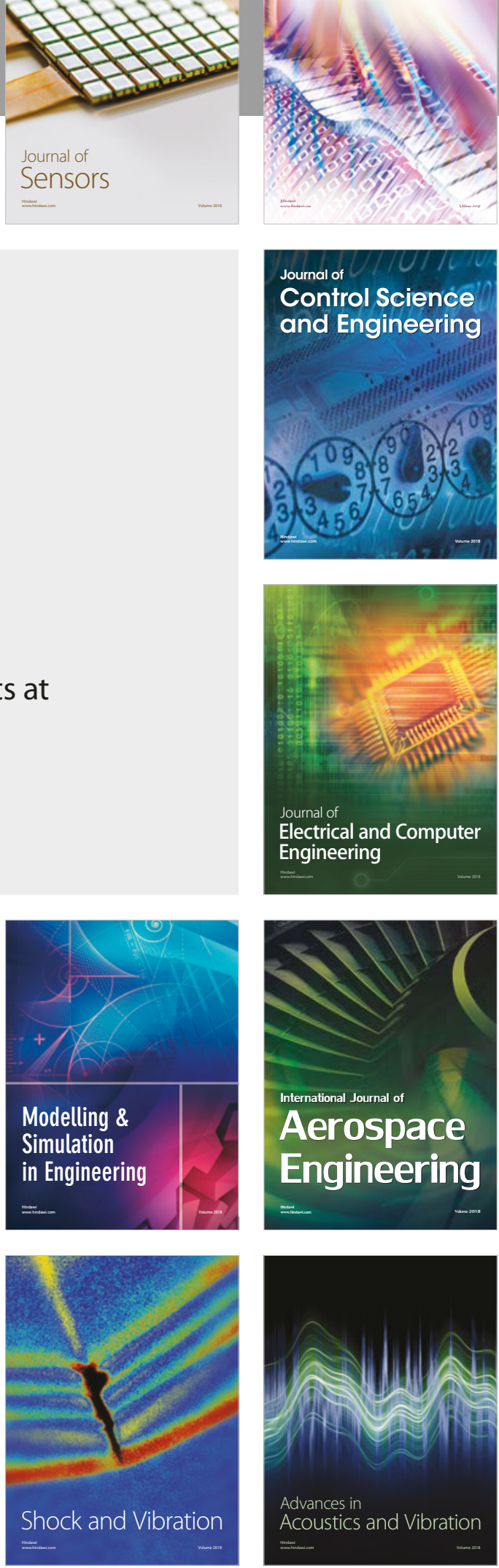